\title{
Role of Oral Calcium and Vitamin D Supplementation in Preventing Post-Thyroidectomy Hypocalcemia
}

\author{
MOSTAFA MAHMOUD SALAMA, M.D. \\ The Department of General Surgery, Faculty of Medicine, Al-Azhar University, Cairo, Egypt
}

\begin{abstract}
Background: Postoperative hypocalcemia is the most frequent complication after total thyroidectomy and its incidence is reported in the literature between 5 and $60 \%$. Manifestations of postoperative hypocalcemia make it a major contributing factor of prolonged hospitalization time which looks mandatory for close observation and repeated laboratory evaluations.
\end{abstract}

Aim of Study: The aim of our study was to detect importance of the use of oral calcium after total thyroidectomy and if it is valuable in preventing symptomatic and laboratory hypocalcemia, and to develop a strategy of oral calcium supplementation following this type of surgery.

Patients and Methods: This is a prospective randomized study conducted on 30 patients undergoing total thyroidectomy for various causes at Al Hussein university hospital from June 2016 to August 2018. Patients were allocated into 2 groups group A (15 patients) and group B (15 patients). Group A will receive supplementation with oral calcium and vitamin $D$ for 3 weeks postoperatively. All patients will be tested for serum calcium and parathormone (PTH) level at day 2, day 7, one month and 3 months postoperatively. Most patients were female and without comorbidities. Multinodular goitre and thyrotoxicosis were the most common diagnosis. Observation of the 2 groups for hypocalcemia (clinically and laboratory) was done.

Results: Symptomatic hypocalcemia in group A and B was found to be $6.6 \%$ and $33.3 \%$ respectively $(p<0.05)$ which is statistically significant. Postoperative day 7 mean serum calcium level for group A and B was found to be $9.18 \pm 0.41$ and $8.11 \pm 0.49 \mathrm{mg} / \mathrm{dl}$ respectively. Postoperative day 7 mean serum parathyroid hormone level for group $\mathrm{A}$ and $\mathrm{B}$ was found to be $46.04 \pm 29.52$ and $36.78 \pm 20.73 \mathrm{pg} / \mathrm{ml}$ respectively.

Conclusion: We conclude that calcium supplementation in the postoperative period effectively decreases the incidence and severity of hypocalcemia following operation involving excision of whole thyroid gland, and can be safely and routinely used after this procedure.

Key Words: Calcium - Vitamin D-Hypocalcemia - Total thyroidectomy.

Correspondence to: Dr. Mostafa Mahmoud Salama, E-Mail: mostafa slama2015@yahoo.com.

\section{Introduction}

POSTOPERATIVE hypocalcemia is considered the most frequently encountered complication following total thyroidectomy. Its incidence is reported in the literature between 5 and $60 \% \quad[2,3]$ Total thyroidectomy is a surgical treatment for many thyroid diseases when the pathologic process involves both lobes of the thyroid gland as in multinodular goitre, Grave's disease, cancer and thyroiditis [1].

Meticulous identification of parathyroid glands with complete preservation is a tough task during thyroid surgery. Sometimes, Inadvertent removal or jeopardization of its blood supply is inevitable. As a result hypoparathyroidism specially after total thyroidectomy is more or less a common event [1] Calcium is the sedater of nerve and, its ionized portion in the body fluids is necessary for many physiological actions including nerve conduction, muscle contraction and blood coagulation. A decrease in extracellular $\mathrm{Ca}++$ exerts an excitatory effect on nervous and muscle tissue.

Hypocalcemia may be asymptomatic when serum calcium $(\mathrm{Ca})$ is mildly decreased. In symptomatic hypocalcemia, the patient has pathognomonic Chvostek's and Trousseau's signs and muscle spasms [4]. Hypocalcaemic tetany is a severe form of hypocalcemia, which is characterized by extensive spasm of skeletal muscle, mostly affecting the muscles of the extremity and larynx [1]. Hypocalcemia typically occurs from 24 to $48 \mathrm{~h}$ after the operation [4].

In addition to patient dissatisfaction after surgery, postoperative hypocalcemia is a major factor of prolonged inpatient admition time which is mandatory in symptomatic patients for close observation and repeated laboratory evaluations [11] 
There is no international agreement on the definition of postoperative hypocalcaemia, thus, many different definitions existed in the literature [5]. The British Association of Endocrine and Thyroid Surgeons (BAETS) sets a definition of postoperative hypocalcaemia as calcium level of less than $2.1 \mathrm{mmol} / \mathrm{L}$ in the first postoperative day [6] The need to take calcium and vitamin D supplement at > 6 months following surgery to maintain normocalcaemia is considered late hypocalcaemia [6]

Various factors contribute to occurrence of postthyroidectomy hypocalcemia such as operating on poorly controlled toxic goiter, hypothermia, significant Vitamin D deficiency, thyrotoxic osteodystrophy, surgery for recurrent goiter, prolonged operative duration, ischemia of most parathyroid glands, devascularization, or inadvertent removal of parathyroids [7]. In addition to importance of quality of surgical technique, there are a variety of practical methods which try to prevent symptomatic hypocalcemia, including oral calcium and vitamin D supplementation which is based on postoperative parathyroid hormone levels, and the routine oral supplementation for all patients without evaluation of parathyroid hormone levels in the post-operative period [8-10]

A number of prospective randomized trials are present in the literature demonstrating the benefits of preoperative and routine postoperative supplementation of calcium and Vitamin D in prevention of transient hypocalcemia [12-14]. Docimo and cols [16] have used calcium and calcitriol in the preoperative and postoperative period, with a $10 \%$ incidence of asymptomatic hypocalcemia and $6 \%$ of symptomatic hypocalcemia. They administered supplementations for 3 days before and 14 days after surgery.

This study is an attempt to throw the light on the same topic after facing a case with tetany who was relative to me, and underwent total thyroidectomy which appeared to be straightforward but became very hypocalcemic postoperative. My search in the literature emphasized importance of such prophylactic practice and encourage me to conduct this study.

\section{Patients and Methods}

This is a prospective randomized controlled study conducted in Al Hussein university hospital from June 2016 to August 2018. The study included 30 patients (between 32 and 57 years) undergoing total thyroidectomy for huge multinodular goitre, cancer thyroid, toxic nodular goitre, Grave,s disease, retrosternal goitre and thyroiditis.
Exclusion criteria included patients with considerable comorbidity, subtotal thyroidectomy, hemithyroidectomy, neck dissection, neck radiation for any reason, patients with chronic renal failure, with parathyroid gland diseases, using calcium supplementation for any chronic disease before the operation and patients with preoperative serum calcium, parathyroid hormone, and albumin level. History, clinical examination and investigations including U/S neck, thyroid function tests (TSH, free T3, free T4) and FNAB were done. All patients underwent a routine preoperative evaluation that included complete blood count, coagulation tests, chest X-ray, and an electrocardiogram with evaluation by a cardiology specialist, if necessary.

Patients diagnosed of having toxic goiter, either primary (Graves disease) or secondary received antithyroid drugs (carbimazole) preoperatively to become controlled in the the euthyroid state.

Data were collected prospectively and informed consent was taken from all patients before inclusion in the study and it was approved by the Ethics Committee at Al-Azhar University.

Preoperative serum albumin, calcium, parathyroid hormone, renal function, hemoglobin, freeT3, free-T4 and TSH level were recorded. Age, sex, body mass index, etiology American Society of Anesthesiologist (ASA) score, thyroid fine needle aspiration (TFNA), presence of drain, blood loss, number of intraoperative preserved parathyroid glands, operative time, pathology, any complication, presence of hypocalcemia, calcium supplementation (oral or IV) were compared between groups.

Patients were divided into two groups; routine $\mathrm{Ca}$ and vitamin D supplementation group (Group A) and no supplementation group (Group B).

Total thyroidectomy was the operation chosen for all patients. Immediately after oral intake was possible after the operation, patients in group A started routine oral calcium and vitamin D supplementation and group B patients received none if symptoms of hypocalcemia were not observed. 48 hours and 7 days postoperatively samples for serum calcium and parathyroid hormone levels were collected from all patients. If asymptomatic hypocalcemia or normal calcium level was present in these patients, they were discharged second postoperative day and controlled on postoperative day 7 at outpatient clinic.

Calcium supplementation (oral or IV) was given if symptomatic hypocalcemia happened and meas- 
urement of serum calcium and parathyroid hormone level on postoperative day 7 was neglected. Symptomatic hypocalcemia was evident if we encounter; perioral or extremity paresthesia, aches or cramps involving any muscle postoperatively, symptoms persistent after postoperative day 3 or patient readmission with hypocalcemia symptoms.

\section{Conduction of total thyroidectomy:}

All of our patients received general anesthesia. The patient is placed in a supine position with the neck extended. A sandbag was placed between the scapulae. The head was placed on a donut cushion, A low collar incision is made $(5-7 \mathrm{~cm})$ and carried down through the subcutaneous tissue and platysma muscle. Subplatysmal flaps are developed, superiorly to the thyroid cartilage level and inferiorly to the suprasternal notch. And the strap muscles are divided vertically in the midline and retracted laterally. Right or left side was approached first depending on which lobe is more affected by the pathology. The thyroid lobe is rotated medially. The middle thyroid vein is ligated. The superior pole of the thyroid is dissected free, and care is taken to identify and preserve the external branch of the superior laryngeal nerve. The superior pole vessels are ligated and cut adjacent to the thyroid lobe, not cephalad to it, to avoid damage to this nerve. This nerve can be seen in mre than $90 \%$ of patients if it is carefully dissected. The inferior thyroid artery and recurrent laryngeal nerve are identified.

The parathyroid gland blood supply should be preserved. This can be done by avoiding ligation the inferior thyroid artery laterally as a single trunk; rather, its branches should be ligated individually on the capsule of the lobe after they have supplied the parathyroid glands. The parathyroid glands are identified, and an attempt is made to leave each with an adequate blood supply while moving the gland off the thyroid lobe.

Recurrent laryngeal nerve should be carefully identified and gently followed along its course. The nerve is gently dissected from surrounding tissue, with much care taken to avoid trauma to it. The nerve is in greatest risk of damage near the junction of the trachea with the larynx, where it is adjacent to the thyroid gland. Once we identified the nerve and parathyroid glands and preserved them, the ligament of Berry can be devided to remove the thyroid lobe. The contralateral thyroid lobe is removed in a similar manner. Careful hemostasis and visualization of all important anatomic structures are mandatory for success. When closing, approximation of the strap muscles in the midline was done then approximating the platysma muscle. Rather, the dermis is approximated by interrupted 4-0 sutures, and the epithelial edges are approximated with a running subcuticular 5-0 polyprolene suture. When it is needed, a small suction catheter is inserted through a small stab wound; it is generally removed within 24 hours.

\section{Serum Ca and PTH hormone assay:}

Serum calcium and parathyroid hormone level blood samples were collected after 48 hrs, 7 days, one month, 3 months from all patients in both groups. Serum intact parathyroid hormone (i-PTH) and total calcium levels were calculated. Normal serum calcium level was $8.4-10.2 \mathrm{mg} / \mathrm{dL}$. Normal serum PTH level was $14-72 \mathrm{pg} / \mathrm{mL}$.

\section{Oral calcium supplementation therapy:}

Patients in group B without symptomatic hypocalcemia were warned for hypocalcemia symptoms and information for readmittance to the hospital was given. Patients in group A and symptomatic patients in group B were given $1 \mathrm{~g}$ elemental calcium TID for first postoperative week, $1 \mathrm{~g}$ elemental calcium BID for second postoperative week, $1 \mathrm{~g}$ elemental calcium Q-day in the third postoperative week (of note, $2.5 \mathrm{~g}$ of calcium carbonate is equivalent to $1 \mathrm{~g}$ of elemental calcium) and one-alpha capsule (0.5 micrograms of alfacalcidol) once daily with calcium. Oral calcium supplementation was terminated gradually for patients with normal serum calcium level on postoperative day 7. Two patient in group B with symptomatic hypocalcemia received intravenous calcium for 2 days. Daily dosage of this patient was twice dose of calcium lactate- gluconate $1000 \mathrm{mg}$ and calcium carbonate $327 \mathrm{mg}$. This patient's serum calcium and parathyroid hormone levels on postoperative day 7 were normal.

\section{Results}

A total of 30 patients were included and half of the patients $(n=15)$ were in group $A$ and half were in group B. Most of the patients were female $(80 \%)$. Most of the patients $(73.3 \%)$ did not have comorbidity. The most common comorbidity was hypertension (13.3\%). 6 (20\%) patients had ASAI score, $22(73.3 \%)$ had ASA-II score and 2 (6.6\%) had ASA-III score. Demographic data of the patients were listed on Table (1). The etiology of thyroid disease was; multinodular goiter 17 (56.6\%) hyperthyroidism $5(16.6 \%)$, cancer $4(13.3 \%)$ and Thyroiditis $2(6.6 \%)$ and Retrosternal goitre 2 $(6.6 \%)$. 
Preoperative thyroid fine-needle aspiration was performed in $14(46.6 \%)$ patients. Intravenous calcium was given to only $2(13.3 \%)$ patient in group B. There was no statistical differences between groups regarding age, sex, comorbidity, ASA score, etiology. Mean operative blood loss was found to be $179 \mathrm{ml}$ for group A and $168 \mathrm{ml}$ for group $\mathrm{B}(p>0.05)$. The average operation time for group A and B was $95 \mathrm{~min}$ and $90 \mathrm{~min}$, respectively (Table 2).

Table (1): Demographic data of patients.

\begin{tabular}{|c|c|c|}
\hline Sex (Female/Male) & & $30(24 / 6)$ \\
\hline Age & & $45.2 \pm 11.89$ \\
\hline $\begin{array}{l}\text { Comorbidity: } \\
\text { NO } \\
\text { Hypertension } \\
\text { DM } \\
\text { COPD }\end{array}$ & & $\begin{array}{l}22(73.3 \%) \\
4(13.3 \%) \\
3(10 \%) \\
1(3.3 \%)\end{array}$ \\
\hline $\begin{array}{l}\text { ASA: } \\
\text { I } \\
\text { II } \\
\text { III }\end{array}$ & & $\begin{array}{l}6(20 \%) \\
22(73.3 \%) \\
2(6.6 \%)\end{array}$ \\
\hline $\begin{array}{l}\text { Preoperative diagnosis: } \\
\text { Multinodular goiter } \\
\text { Hyperthyroidism } \\
\text { Cancer thyroid } \\
\text { Thyroiditis } \\
\text { Retrosternal goitre }\end{array}$ & & $\begin{array}{l}17(56.6 \%) \\
5(16.6 \%) \\
4(13.3 \%) \\
2(6.6 \%) \\
2(6.6)\end{array}$ \\
\hline $\begin{array}{l}\text { FNAB: } \\
\text { YES } \\
\text { NO }\end{array}$ & & $\begin{array}{l}14(46.6 \%) \\
16(53.3 \%)\end{array}$ \\
\hline $\begin{array}{l}\text { Postoperative histopathologic } \\
\text { Simple multinodular goiter } \\
\text { Hashimoto thyroiditis } \\
\text { Papillary thyroid carcinoma } \\
\text { Follicular thyroid carcinoma } \\
\text { Toxic goiter }\end{array}$ & al results: & $\begin{array}{l}17(56.6 \%) \\
2(6.6 \%) \\
2(6.6 \%) \\
4(13.3 \%) \\
5(16.6 \%)\end{array}$ \\
\hline \multicolumn{3}{|c|}{$\begin{array}{l}\text { Abbreviations: } \\
\text { ASA : American society of Anesthesiologists. } \\
\text { COPD: Chronic obstructive pulmonary disease. } \\
\text { DM : Diabetes mellitus. }\end{array}$} \\
\hline & $\begin{array}{l}\text { Calcium } \\
\text { supplementation } \\
\text { Group A }(n=15)\end{array}$ & $\begin{array}{l}\text { No calcium } \\
\text { supplementation } \\
\text { Group B }(n=15)\end{array}$ \\
\hline Operation time (mean) & $95 \mathrm{~min}$ & $90 \mathrm{~min}$ \\
\hline Blood loss (mean) & $179 \mathrm{ml}$ & $168 \mathrm{ml}$ \\
\hline Symptomatic hypocalcemia & $1(6.6 \%)$ & $5(33.3 \%)$ \\
\hline Asymptomatic hypocalcemia & $2(13.3 \%)$ & $0(0 \%)$ \\
\hline $\begin{array}{l}\text { Calcium supplementation } \\
\text { (i.v.) }\end{array}$ & $0(0 \%)$ & $2(13.3 \%)$ \\
\hline $\begin{array}{l}\text { Serum calcium } \\
\quad(\text { postop. day } 7)(\mathrm{mg} / \mathrm{dl})\end{array}$ & $9.18 \pm 0.41$ & $8.11 \pm 0.49$ \\
\hline $\begin{array}{l}\text { Serum PTH } \\
\quad(\text { postop. day } 7)(\mathrm{pg} / \mathrm{ml})\end{array}$ & $46.04 \pm 29.52$ & $36.78 \pm 20.73$ \\
\hline Complications & $0(0 \%)$ & $0(0 \%)$ \\
\hline
\end{tabular}

Abbreviations: PTH: Parathyroid hormone.
The mean day that symptomatic hypocalcemia seen in group B patients was found to be $2.72 \pm 1.01$ days (between 2 and 6 days). Symptomatic hypocalcemia for group A and B was found to be $6.6 \%$ and $33.3 \%$ respectively $(p<0.05)$ which is statistically significant. Mean postoperative 7 day serum calcium level for group A and B was found to be $9.18 \pm 0.41$ and $8.11 \pm 0.49 \mathrm{mg} / \mathrm{dl}$ respectively. Mean postoperative 7 day serum parathyroid hormone level for group A and B was found to be $46.04 \pm$ 29.52 and $36.78 \pm 20.73 \mathrm{pg} / \mathrm{ml}$. respectively. All 2 (6.6\%) patients with asymptomatic hypocalcemia were in group A $(p<0.05)$.

Hypoparathyroidism was observed in 1 patients (3.3\%) which was not statistically different. No complication other than hypoclcemia was observed in all patients. All four parathyroid glands were identified and preserved in 25 patients $(83.3 \%)$, while 5 glands were identified in 3 patients $(10 \%)$ and 3 glands in 2 patients $(6.6 \%)$.

Postoperative histopathological results were simple multinodular goiter in 17 patients, hashimoto thyroiditis in 2 patients, papillary thyroid carcinoma in 2 patients and follicular thyroid carcinoma in 4 patients. Toxic goiter in 5 patients.

Table (3): Comparison between the studied groups according to S-Ca level.

\begin{tabular}{|c|c|c|c|c|}
\hline Serum calcium level & $\begin{array}{l}\text { Group } \\
\text { A (15) }\end{array}$ & $\begin{array}{l}\text { Group } \\
\text { B (15) }\end{array}$ & $t$ & $p$-value \\
\hline \multicolumn{5}{|l|}{ Preoperative: } \\
\hline Minimum-maximum & $9.11-10.4$ & $9.11-10.36$ & 0.53 & 0.6 \\
\hline Mean \pm SD & $9.72 \pm 0.36$ & $9.65 \pm 0.40$ & & \\
\hline Median & 9.76 & 9.56 & & \\
\hline \multicolumn{5}{|l|}{48 h postoperative: } \\
\hline Minimum-maximum & 7.9-9.9 & $7.4-9.58$ & 2.937 & 0.007 \\
\hline Mean \pm SD & $8.86 \pm 0.54$ & $8.48 \pm 1.64$ & & \\
\hline Median & 9.5 & 8.4 & & \\
\hline \multicolumn{5}{|l|}{7 days: } \\
\hline Minimum-maximum & $8.2-9.3$ & $7.33-9.22$ & 2.84 & 0.014 \\
\hline Mean \pm SD & $9.18 \pm 0.41$ & $8.11 \pm 0.49$ & & \\
\hline Median & 9.40 & 8.51 & & \\
\hline \multicolumn{5}{|l|}{1 month: } \\
\hline Minimum-maximum & $9.20-10.20$ & $7.80-9.7$ & 4.462 & 0.001 \\
\hline Mean \pm SD & $9.79 \pm 0.26$ & $9.31 \pm 0.33$ & & \\
\hline Median & 9.80 & 9.11 & & \\
\hline \multicolumn{5}{|l|}{3 months: } \\
\hline Minimum-maximum & $9.60-10.80$ & $9.40-10.60$ & 2.544 & 0.017 \\
\hline Mean \pm SD & $10.19 \pm 0.33$ & $9.87 \pm 0.37$ & & \\
\hline Median & 10.20 & 9.80 & & \\
\hline
\end{tabular}

$t, p$ : $t$ and $p$-value for student's $t$-test for comparing the two groups. $p<0.05$ is statiscally significant. 
Table (4): Comparison between the studied groups according to S-PTH level.

\begin{tabular}{|c|c|c|c|c|}
\hline Serum calcium level & $\begin{array}{l}\text { Group } \\
\text { A (15) }\end{array}$ & $\begin{array}{l}\text { Group } \\
\text { B (15) }\end{array}$ & $t$ & $p$-value \\
\hline \multicolumn{5}{|l|}{ Preoperative: } \\
\hline Minimum-maximum & $34.89-68.46$ & $35.03-67.70$ & 0.927 & 0.362 \\
\hline Mean \pm SD & $47.63 \pm 8.96$ & $50.77 \pm 11.08$ & & \\
\hline Median & 47.12 & 50.34 & & \\
\hline \multicolumn{5}{|l|}{48 h postoperative: } \\
\hline Minimum-maximum & $31.25-57.02$ & $28.42-57.90$ & 0.114 & 0.910 \\
\hline Mean \pm SD & $43.20 \pm 7.41$ & $43 \pm 10.0$ & & \\
\hline Median & 42.69 & 46.13 & & \\
\hline \multicolumn{5}{|l|}{7 days: } \\
\hline Minimum-maximum & $33.2-56.3$ & $30.0-67.12$ & 1.030 & 0.087 \\
\hline Mean \pm SD & $46.04 \pm 29.52$ & $36.78 \pm 20.73$ & & \\
\hline Median & 41.65 & 43.22 & & \\
\hline \multicolumn{5}{|l|}{1 month: } \\
\hline Minimum-maximum & $28.92-37.90$ & $26.83-36.40$ & 1.076 & 0.291 \\
\hline Mean \pm SD & $34.08 \pm 2.74$ & $32.98 \pm 2.84$ & & \\
\hline Median & 34.71 & 33.52 & & \\
\hline \multicolumn{5}{|l|}{3 months: } \\
\hline Minimum-maximum & $31.41-59.12$ & $27.15-54.68$ & 0.356 & 0.724 \\
\hline Mean \pm SD & $45.54 \pm 7.04$ & $44.50 \pm 8.89$ & & \\
\hline Median & 45.18 & 48.13 & & \\
\hline
\end{tabular}

PTH: Parathormone hormone.

$t, p: t$ and $p$-value for student's $t$-test for comparing the two groups. $p<0.05$ is statiscally significant.

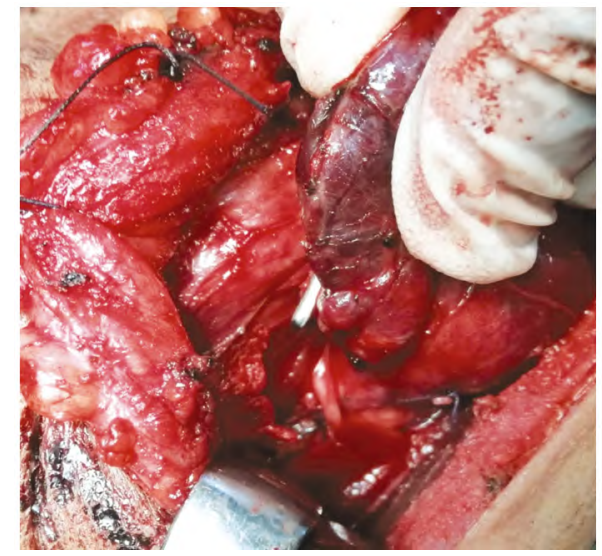

Fig. (1): Accidental finding of nonrecurrent right recurrent laryngeal nerve during total thyroidectomy for controlled toxic goitre.

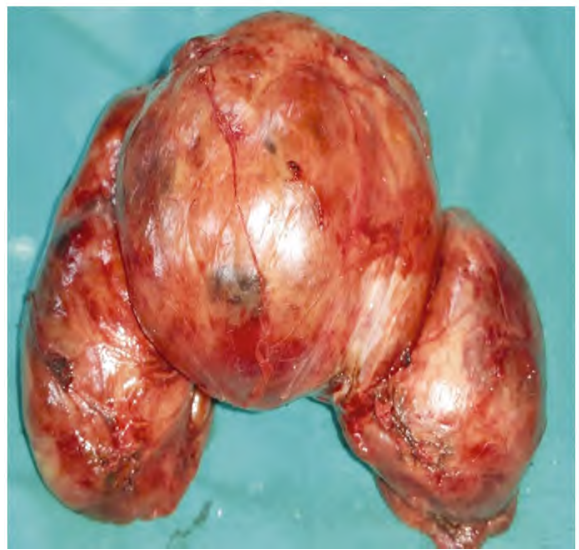

Fig. (3): Very large goitre removed from patient presented by dyspnea.

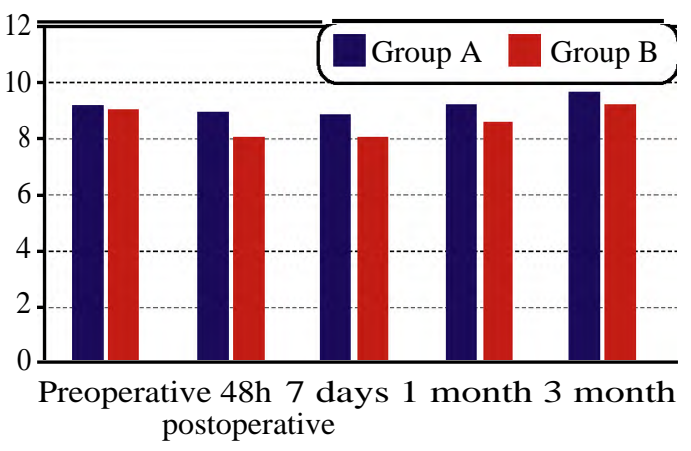

Diagram (1): Comparison between the studied groups according to S-Ca level.

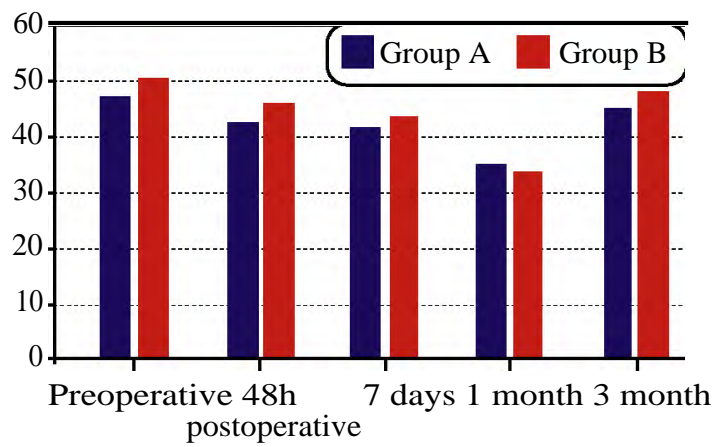

Diagram (2): Comparison between the studied groups according to S-PTH level.

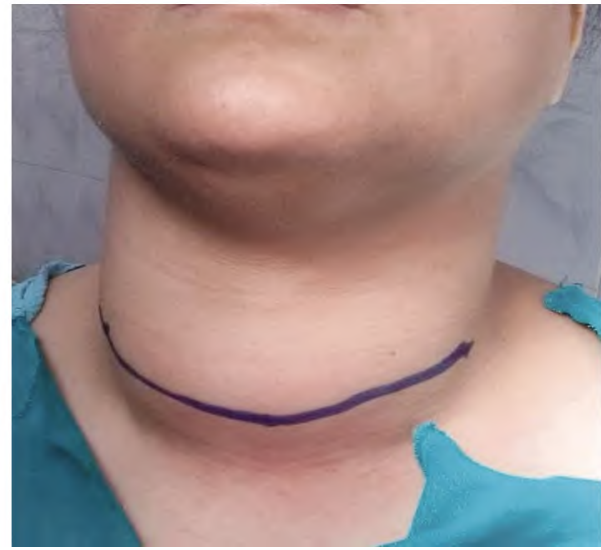

Fig. (2): Patient with huge benign multinodular goitre.

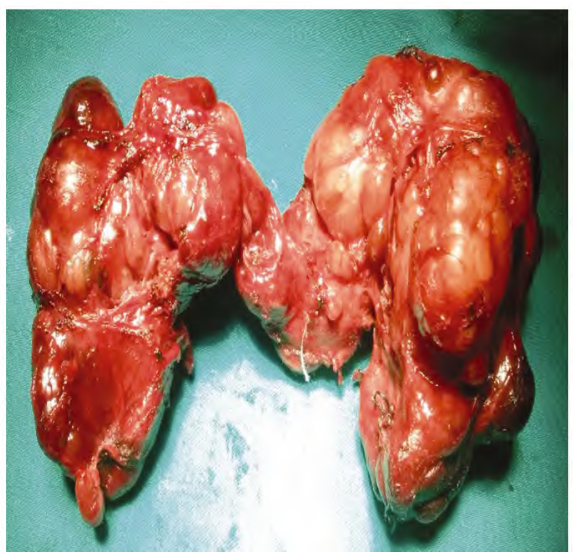

Fig. (4): Total thyroidectomy for the patient in Fig. (2). 


\section{Discussion}

Parathyroid glands were described for the first time in rhinoceros by Owen (india) in 1852 [cited by Thompson] [17]. However, the relationship between post-thyroidectomy hypocalcemia and parathyroid glands injury or resection was only proven in 1891. The first report that describe tetany after thyroidectomy was in 1877 [18].

Occurrence of postoperative hypocalcemia mandates prolongation of hospital stay and multiple blood samplings for serial monitoring of serum calcium or PTH levels [19]. Because hypocalcemia can not be detected before postoperative $24-48 \mathrm{~h}$, most surgeons used to be hesitated to discharge patients before $48 \mathrm{~h}$ [20].

By using PTH as an early biomarker of hypocalcemia early discharge of these patients can be considered by measuring i-PTH levels wthin $24 \mathrm{~h}$ postoperative [20]. Raffaelli et al., reported possible association between normal.

PTH level and occurrence of hypocalcemia in the early postoperative period [21]. PTH is therefore, not precisely effective in predicting hypocalcemia. Seeking calcium supplementation therapy and neglecting early predictors seems an acceptable option in this circumstance.

In majority of cases, hypocalcemia exerts positive feedback on parathyroids and resolves spontaneously. Hungery bones in thyrotoxic osteodystrophy, will prolong duration of hypocalcemia. Iatrogenic devascularization and/or inadvertent removal of the parathyroid glands render the patient hypoparathyroid or aparathyroid [22]. Malignancy may require lymph node dissection, which would warrant extensive dissection with increased risk of vascular compromise to the parathyroid end arteries or inadvertent parathyroid gland injury. This is more commonly seen in patients undergoing central neck lymph node dissection [23].

In order to reduce the manifestations of postoperative hypocalcemia, oral calcium and vitamin D supplementation were used as a routine following total thyroidectomy to support the calcium level from the decline in the early postoperative days. This supplementation regimen was applied to the treatment group, while we did not give any supplementation to the control group.

In previous studies, regimens of oral calcium alone and of the combination of calcium and vitamin D were effective. However, Bellantone et al., in 2002 [24]. published that the adding vitamin D to oral calcium supplements significantly caused higher serum calcium concentrations on days 2 and 3 postoperative and with a lower rate of hypocalcemia. Also, they reported in their study that only three of twenty six patients $(11 \%)$ receiving oral calcium supplement ( $3 \mathrm{~g} / \mathrm{d})$ had hypocalcemic symptoms following total thyroidectomy, while 11 of 27 patients (40\%) not receiving calcium had symptoms [24].

The dosages and durations of calcium and vitamin D administration are also of concern. ElShinawi et al., shows that routine oral calcium $(1.5 \mathrm{gm} /$ day $)$ and vitamin $\mathrm{D}(0.5 \mu \mathrm{g} /$ day $)$ decreases the incidence of hypocalcemia after total thyroidectomy [25] . In our study, patients were given $1 \mathrm{~g}$ elemental calcium TID for the first postoperative week, $1 \mathrm{~g}$ elemental calcium BID for second postoperative week, $1 \mathrm{~g}$ elemental calcium Q-day in the third postoperative week (Of note, $2.5 \mathrm{~g}$ of Calcium carbonate is equivalent to $1 \mathrm{~g}$ of elemental calcium) and one-alpha capsule (0.5 micrograms of alfacalcidol) once daily with calcium. The incidence of hypocalcemia in the control group was $33.3 \%$ compared to $20 \%$ in the treatment group. Symptomatic hypocalcemia occurred in 6 patients (20\%). Control group had 5 patients, not receiving supplement $(33.3 \%)$ and the treatment group had 1 patients $(6.6 \%)$. In the supplement group, hypocalcemic symptoms were minimal and patients did not complain of severe hypocalcemic symptoms. Hypocalcemic symptoms occurred more severely in the group that did not had supplement. In the control group, 2 patients experienced carpopedal spasms and they needed intravenous calcium administration. In contrast, none of the treatment group had carpopedal spasm and required intravenous calcium.

Moreover, Table (3) showed that supplemental treatment prevented a major decrease of serum calcium levels as well as the subsequent development of severe hypocalcemic symptoms after total thyroidectomy. Total calcium values measured at postoperative days 2 and 7, one month, 3 month were lower in the group not receiving supplement than in the supplement group $(p<0.05)$.

Our results are similar to the study done by Jong-Lyel Roh et al., [26] in 2006, which showed that postoperative treatment had prevented a significant reduction of serum calcium levels after total thyroidectomy. In the supplement group, hypocalcemic symptoms were minimal that patients did not experience any carpopedal spasm. This is different from the control group, where three patients suffered from carpopedal spasms and five 
patients needed intravenous calcium therapy after their persistent severe hypocalcaemia failed to subside on subsequent administration of oral calcium and vitamin D supplements.

Roh et al., conducted a study in 2009, [27] on patients following total thyroidectomy and central neck dissection for differentiated papillary carcinoma which showed that routine oral calcium and vitamin D supplements greatly reduced the incidence of post-thyroidectomy hypocalcemia.

If significant symptomatic hypocalcemia is prevented or rduced, decision for early discharge of post-thyroidectomy patients from the hospital will be easily taken. Stiges et al., in 2010 [28] discovered that although it is very advantageous for patients, multiple blood samplings and extended hospitalization increase the total cost of the medical healthcare system. In our study, the hospital stay after total thyroidectomy decreased from $2.78 \pm 1.44$ days in the control group to $2.26 \pm 0.21$ in the treatment group. However it did not reach a significant value.

A meta-analysis conducted by Alhefdhi et al., involved 2285 patients, enrolled in 9 studies, showed a significant decrease in the rate of symptomatic hypocalcemia in groups treated with vitamin D and calcium as compared to no prophylaxis or calcium alone [29]

Another meta-analysis assessed many preventative and surgical measures performed to decrease the rate of post-thyroidectomy hypocalcaemia, [30] in which combined calcium and vitamin D supplements were found to decrease the rates of transient postoperative hypocalcaemia significantly more than either calcium alone or no supplements.

Similar results were shown by Pisaniello et al., in which early and combined administration of both oral calcium and Vitamin D has greatly prevented postoperative hypocalcemia [31]

\section{Conclusion:}

We conclude that calcium supplementation in the postoperative period effectively decreases the incidence and severity of hypocalcemia after total thyroidectomy, and can be safely and routinely used after this procedure. The presented strategy of oral calcium supplementation may be implemented in a viable manner.

\section{Ethical approval:}

Ethical approval was taken from Al-Azhar University Ethical Committee.
Conflicts of interest:

None.

\section{References}

1- BISWAS N.N., CHAUDHURY W.A., KHAN J.A., BISWAS A.C., ARIF K.M., GHOSH S. and AKTER S.: Hypocalcaemic Tetany After Total Thyroidectomy, Faridpur Med. Coll. J., 10 (2): 59-62, 2015.

2- PAGE C. and STRUNSKI V.: Parathyroid risk in total thyroidectomy for bilateral, benign, multinodular goitre: Report of 351 surgical cases J. Laryngol. Otol., 121: pp. 237-241, 2007.

3- ROSATO L., AVENIA N., BERNANTE P., et al.: Complications of thyroid surgery: Analysis of a multicentric study on 14,934 patients operated on in Italy over 5 years World J. Surg., 28: pp. 271-276, 2004.

4- CHIA S.H.,WEISMAN R.A., KELLY C., DILLMANN W.H. and ORLOFFPROSPECTIVE L.A.: Study of perioperative factors predicting hypocalcemia after thyroid and parathyroid surgery Arch. Otolaryngol. Head. Neck Surg., 132: pp. 41-45, 2006.

5- MEHANNA H.M., JAIN A., RANDEVA H., et al.: Postoperative hypocalcemia--the difference a definition makes. Head Neck, 32: 279-83, 2010

6- CHADWICK D.: The British association of endocrine and thyroid surgeons, fifth national audit report. Oxfordshire: Dendrite Clinical Systems, 2017.

7- KRISHNAN RAVIKUMAR, DHALAPATHY SADACHARAN, SANKARAN MUTHUKUMAR, THALAVAI SUNDARRAM, SELLADURAI PERIYASAMY and SURESH R.V.: A Prospective Study on Role of Supplemental Oral Calcium and Vitamin D in Prevention of Postthyroidectomy Hypocalcemia. Indian. J. Endocrinol. Metab. Jul-Aug., 21 (4): 498-503, 2017.

8- SYWAK M.S., PALAZZO F.F., YEH M., et al.: Parathyroid hormone assay predicts hypocalcaemia after total thyroidectomy. ANZ journal of surgery. Aug.,77 (8): 667670, 2007.

9- WANG T.S., CHEUNG K., ROMAN S.A. and SOSA J.A.: To supplement or not to supplement: A cost-utility analysis of calcium and vitamin D repletion in patients after thyroidectomy. Annals of surgical oncology. May, 18 (5): 1293-1299, 2011

10- BURCH H.B., BURMAN K.D. and COOPER D.S.: A 2011 survey of clinical practice patterns in the management of Graves' disease. The Journal of clinical endocrinology and metabolism. Dec., 97 (12): 4549-4558, 2012.

11- BHATTACHARYYA N. and FRIED M.P.: Assessment of morbidityabd complications of total thyroidectomy. Arch Otolaryngol Head Neck Surg., 128 (4): 389-392, 2002.

12- BELLANTONE R., LOMBARDI C.P., RAFFAELLI M., BOSCHERINI M., ALESINA P.F., DE CREA C., et al. Is routine supplementation therapy (calcium and Vitamin D) useful after total thyroidectomy? Surgery, 132: 110912, 2002.

13- ROH J.L. and PARK C.I.: Routine oral calcium and Vitamin D supplements for prevention of hypocalcemia after total thyroidectomy. Am. J. Surg., 192: 675-8, 2006. 
14- KURUKAHVECIOGLU O., KARAMERCAN A., AKIN M., TEZEL E., EGE B., TANERI F., et al.: Potential benefit of oral calcium/Vitamin D administration for prevention of symptomatic hypocalcemia after total thyroidectomy. Endocr. Regul., 41: 35-9, 2007.

15- KRISHNAN RAVIKUMAR, DHALAPATHY SADACHARAN, SANKARAN MUTHUKUMAR, THALAVAI SUNDARRAM, SELLADURAI PERIYASAMY and SURESH R.V. : A Prospective Study on Role of Supplemental Oral Calcium and Vitamin D in Prevention of Postthyroidectomy Hypocalcemia. Indian J. Endocrinol. Metab.Jul-Aug., 21 (4): 498-503, 2017.

16- DOCIMO G., TOLONE S, PASQUALI D., CONZO G., D'ALESSANDRO A., CASALINO G., et al.: Role of pre and post-operative oral calcium and vitamin D supplements in prevention of hypocalcemia after total thyroidectomy. G. Chir., 33 (11-12): 374-8, 2012.

17- THOMPSON N.W.: The history of hyperparathyroidism. Acta Chir. Scand., 156: 5-21, 1990.

18- ARAÚJO FILHO V.J.F., MACHADO M.T.A.S., SONDERMANN A., CARLUCCI J.R.D., MOYSÉS R.A. and FERRAZ A.R.: Hipocalcemia e hipoparatireoidismo clínico após tireoidectomia total. Rev. Col. Bras. Cir., 31 (4): 233-5, 2004.

19- ROH J.L. and PARK C.I.: Routine oral calcium and Vitamin D supplements for prevention of hypocalcemia after total thyroidectomy. Am. J. Surg., 192: 675-8, 2006.

20- ILKER MURAT ARER, MURA TKUS, NEZIH AKKAPULU, HUSEYIN OZGUR AYTAC, HAKANYABANOGLU, KENAN CALISKAN and MEHMET AKINTARIM: Prophylactic oral calcium supplementation therapy to prevent early post thyroidectomy hypocalcemia and evaluation of postoperative parathyroid hormone levels to detect hypocalcemia: A prospective randomized study. International Journal of Surgery, Volume 37, Supplement 1, January-December Pages, 148, 2017,

21- RAFFAELLI M., DE CREA C., D'AMATO G., et al.: Post-thyroidectomy hypocalcemia is related to parathyroid dysfunction even in patients with normal parathyroid hormone concentrations early after surgery Surgery, 159 (1) $78-84,2016$.

22- KURUKAHVECIOGLU O., KARAMERCAN A., AKIN M., TEZEL E., EGE B., TANERI F., et al.: Potential benefit of oral calcium/Vitamin D administration for prevention of symptomatic hypocalcemia after total thyroidectomy. Endocr. Regul., 41: 35-9, 2007.

23- LIN D.T., PATEL S., SHAHA A.R., SINGH B. and SHAH J.P.: Incidence of inadvertent parathyroid removal during thyroidectomy Laryngoscope, 112: 608-11, 2002.

24- BELLANTONE R., LOMBARDI C.P., RAFFAELLI M., BOSCHERINI M., ALESINA P.F., DE CREA C., et al.: Is routine supplementation therapy (calcium and vitamin D) useful after total thyroidectomy? Surgery, 132: 1109$12,2002$.

25- EL-SHINAWI M., EL-ANWAR A., NADA M., YOUSSEF T., FAKHRY E., RASLAN S. and EL-GOHRY H.: Oral calcium and vitamin D supplementation after total thyroidectomy. Thyroid Res. Pract., 11: 98-102, 2014.

26- ROH J.L. and PARK C.I.: Routine oral calcium and vitamin D supplements for prevention of hypocalcemia after total thyroidectomy. Am. J. Surg., 192: 675-8, 2006.

27- ROH J.L., PARK J.Y. and PARK C.I.: Prevention of postoperative hypocalcaemia with routine oral calcium and vitamin d supplements in patients with differentiated papillary thyroid carcinoma undergoing total thyroidectomy plus neck dissection. Cancer, 115: 251-8, 2009.

28- STIGES-SERRA A., RUIZ S., GIRVENT M., MANJÓN H., DUEÑAS J.P. and SANCHO J.J.: Outcome of protracted hypoparathyroidisim after total thyroidectomy. Br. J. Surg., 97: 1687-95, 2010

29- ALHEFDHI A., MAZEH H. and CHEN H.: Role of postoperative Vitamin D and/or calcium routine supplementation in preventing hypocalcemia after thyroidectomy: A systematic review and meta-analysis. Oncologist., 18: 533-42, 2013

30- ANTAKIA R., EDAFE O., UTTLEY L., et al.: Effectiveness of preventative and other surgical measures on hypocalcemia following bilateral thyroid surgery: A systematic review and meta-analysis. Thyroid, 25: 95106, 2015.

31- PISANIELLO D., PARMEGGIANI D., PIATTO A., AVENIA N., D'AJELLO M., MONACELLI M., et al.: Which therapy to prevent post-thyroidectomy hypocalcemia? G. Chir., 26: 357-61, 2005. 


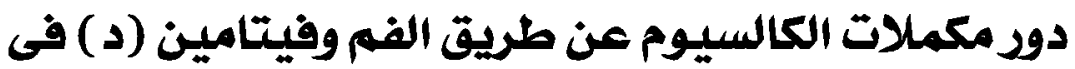

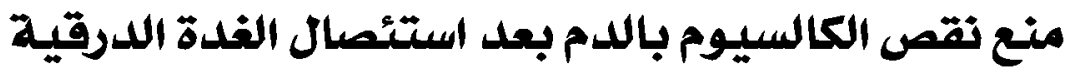

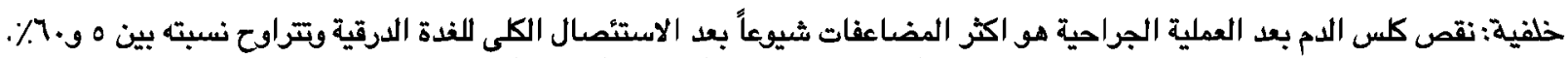

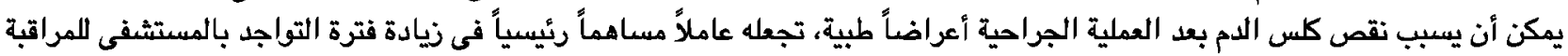

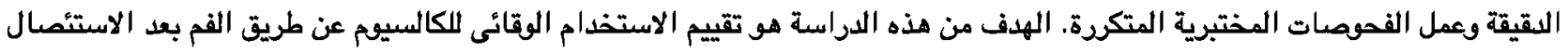
الكلى للفدة الدرقية فى الوقاية من نقص كلس الدم، وتطوير استراتيجية لاعطاء مكملات الكالسيقم عن طريق الفم بعد هذا النوع من الجراحة.

المرضى والطرق: هذه دراسة عشوائية مستقبلية أجريت على • ب مريضاً يخضعون للاستئصال الكلى للغدة الدرقية لأسباب مختلفة فى ألى

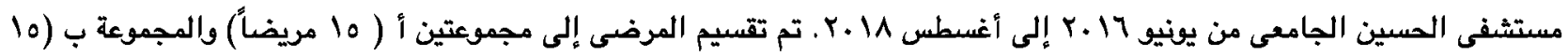

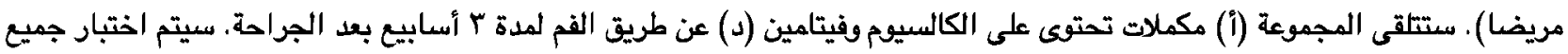

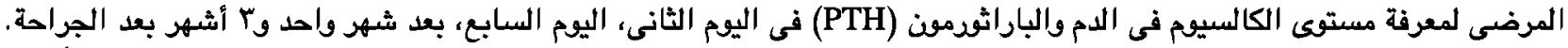

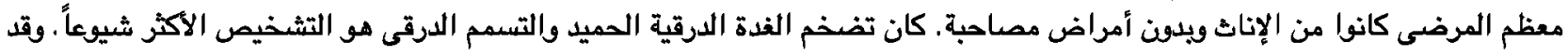
تم مراقبة نقص كلس الدم فى المجموعتين (سريريا ومختبريا).

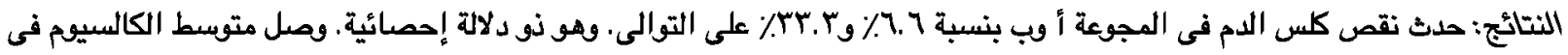

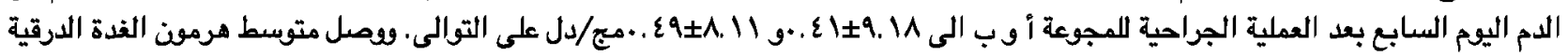

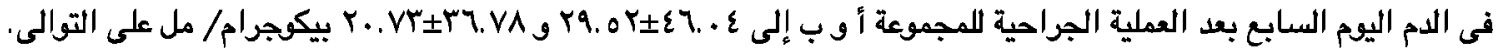

الخلاصة: نشتتتج أن مكملات الكالسوم بعد العملية الجراحية تمنع بشكل فعال نقص الكالسيوم فى الدم (عرضياً ومختبرياً) بعد الاستئصال

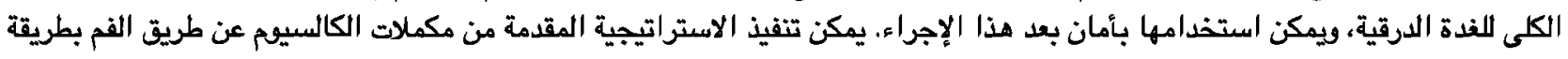

